\title{
Cohort growth of planktotrophic polychaete larvae-are they food limited?
}

\author{
Benni Winding Hansen* \\ Roskilde University, Institute I, Life Sciences and Chemistry, PO Box 260, DK-4000 Roskilde, Denmark
}

\begin{abstract}
A $16 \mathrm{~d}$ mesocosm experiment was performed during summer 1995 with $6 \mathrm{~m}^{3}$ bags filled with natural fjord water and plankton in a Danish embayment, Knebel Vig. Two control mesocosms simulated in situ conditions and a further 2 were enriched with inorganic nutrients to stimulate the primary producers. Zooplankton food availability in terms of 2 to $20 \mu \mathrm{m}$ particles in the control and the enriched mesocosms revealed a mean \pm SD of $582 \pm 109$ and $1191 \pm 505 \mu \mathrm{g} \mathrm{Cl}^{-1}$, respectively. The major increase of particulate carbon in the enriched mesocosms was due to a bloom of the cryptophyte Hemiselmis virescens. Cohorts of the polychaete larvae Polydora spp., Spio/Microspio spp. and Nereis (Neanthes) succinea were identified. The natural instantaneous mortality rate of the larvae revealed a mean of 0.16 and $0.37 \mathrm{~d}^{-1}$ in the control and enriched mesocosms, respectively. Mean growth in terms of setiger increase, body length increase and carbon content increase showed a fast growth phase followed by a stationary phase for Polydora spp. and Spio/Microspio spp. During the fast growth phase Polydora spp. had a specific growth rate of 0.21 to $0.31 \mathrm{~d}^{-1}$ in both the control and the enriched mesocosms. A statistically non-significant higher pragmatic mean specific growth rate was found when enriched phytoplankton was offered Spio/Microspio spp. (both controls $0.20 \mathrm{~d}^{-1}$, enriched 0.25 and $0.28 \mathrm{~d}^{-1}$ ). N. (Neanthes) succinea grew more continuously throughout the study and in 1 of the enriched mesocosms with a significantly higher mean value 0.15 and $0.16 \mathrm{~d}^{-1}$ in controls and 0.19 and $0.31 \mathrm{~d}^{-1}$ in enriched mesocosms). This indicates functionally food limited growth for polychaete larvae in this summer situation despite high particulate carbon content in the controls.
\end{abstract}

KEY WORDS: Planktotrophic polychaete larvae · Polydora spp. - Spio/Microspio spp. · Nereis (Neanthes) succinea $\cdot$ Mortality $\cdot$ Growth $\cdot$ Food limitation $\cdot$ Mesocosm

\section{INTRODUCTION}

At certain periods and locations the abundance of planktotrophic polychaete larvae can reach quite high numbers in coastal waters. Due to high densities of benthic dwelling individuals, Zarac (1991) has reported an annual Polydora ligni larval production of close to 900000 larvae $\mathrm{m}^{-2}$ in Alevife Cowe, Connecticut, USA. Daro \& Polk (1973) reported a peak abundance of Polydora ciliata larvae of 525 ind. $1^{-1}$ off the coast of Belgium and Bochert et al. (1996b) showed an abundance of Marenzelleria viridis larvae of 1000 ind. $\mathrm{I}^{-1}$ in the Baltic Sea in September. Jørgensen (1981) showed a 30 to $40 \%$ daily clearance of the water column for nanoplankton by blue mussel veligers in a

•E-mail: bhansen@ruc.dk
Danish fjord. Hence, these planktotrophic polychaete larvae must, in concert with other ciliated meroplankton, occasionally play a significant role as grazers upon the primary producers.

Despite a potential role in the pelagic carbon flow, limited basic knowledge is available about polychaete larvae, e.g. descriptions of body length versus weight relations to determine standing stocks, grazing, growth and mortality in situ. Additionally only a few studies identify relevant prey items for these organisms. It has been suggested that spionid larvae graze upon phytoplankton (diatoms), are occasionally cannibalistic (George 1966, Simon 1968), and graze upon nanoplankton below $20 \mu \mathrm{m}$ in size (Daro \& Polk 1973). Most of the detailed information about particle grazing has been provided from laboratory rearing studies where e.g. larvae from the spionid Spio setosa have been cultivated on Phaeodactylum tricornutum (Simon 
1968). The spionid larvae Polydora ciliata and Polydora ligni have been reared on Dunaliella tertiolecta and Thalassiosira rotula (Anger et al, 1986), and several other larval species have been cultivated likewise (Hansen 1993, Bochert et al. 1996a). However, Daro \& Polk (1973) reported that settling competent $P$. ciliata is carnivorous and detritivorous and not at all selective. Generally, this information suggests that a great deal of the food source for polychaete larvae in their fast growth phase (from trochophore to stationary growth) is particles in the size range of 2 to $20 \mu \mathrm{m}$.

In order to evaluate the significance of planktotrophic polychaete larval grazing, in situ rates of growth are relevant. However, only limited information is available in the literature. Rice 1975, in Zarac 1991) reported that Polydora ligni developed from hatching to metamorphosis within $18 \mathrm{~d}$ at $20^{\circ} \mathrm{C}$, and $P$. ciliata has been reported to have a pelagic life of $14 \mathrm{~d}$ in the Bassin de Chasse, Belgium (Daro \& Polk 1973). Anger et al. (1986) reported a pelagic phase of 9 to $11 \mathrm{~d}$ for $P$. ligni and $P$. ciliata, both reared in the laboratory at $18^{\circ} \mathrm{C}$ and offered food in excess. Neanthes succinea develop from trochophore to settling stage within $11 \mathrm{~d}$ in Danish waters (Kirkegaard 1992).

Recently Metaxas \& Young (1998) suggested that echionid larvae perform aggregative behaviour in food patches. Whether meroplankton generally experience

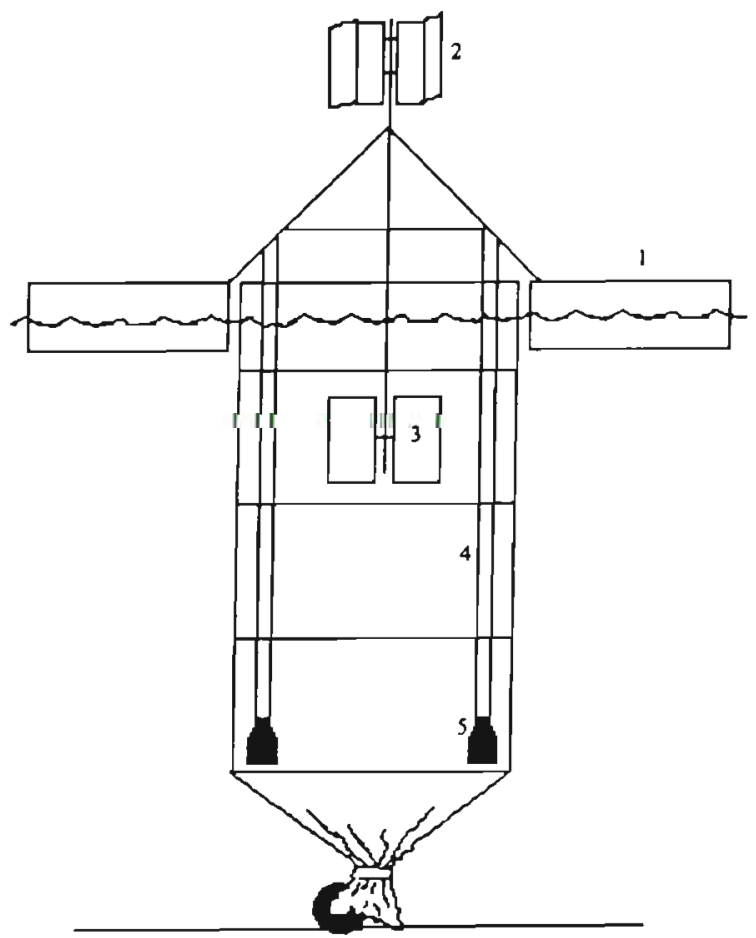

Fig 1 Outline of the mesocosms employed. 1: pontoon raft where the mesocosms were attached; 2 : wind mill; 3 : flatplated stirrer; 4 : settling strips; 5 : weight to keep the settling strips suspended food limitation in situ has been reviewed by e.g. Olson \& Olson (1989) by subjecting larvae to starvation or offering them collected natural sea water and sea water enriched by cultivated algal material. The conclusion was '... larval starvation is frequently important in crustaceans, occasionally important in molluscs, and rarely, if ever, important in echinoderms'. Recent literature does not clarify the question of whether ciliated meroplankton experience food limited growth. Widespread food limited growth in many coastal waters for echinoplutei (Fenaux et al. 1994) and for larvae of sand dollar (Eckert 1995) has been argued. For bivalve larvae, food limited growth is not clear for Crassostrea virginica (Baldwin \& Newell 1995) but strongly indicated for Mytilus edulis (Fotel et al. 1999). One of the few experiments with polychaete larvae is reported by Pauley et al. (1985), wherein food limited growth was determined for Serpula vermicularis offered the in situ food concentration. The overall impression is that food limited growth occurs occasionally in polychaete larvae.

In the present study I have used cohort analysis of naturally occurring polychaete larvae enclosed in $6 \mathrm{~m}^{3}$ mesocosms as a tool for describing larval development and growth as well as mortality. Naturally occurring polychaete larvae were raised in natural fjord water and nutrient enriched fjord water in an attempt to answer the question of whether polychaete larvae can be expected to be food limited in a Danish fjord during summer

\section{MATERIALS AND METHODS}

The growth experiment was performed in a lowenergy embayment (Knebel Vig, Denmark) from July 17 to August 2, 1995. Knebel Vig is a small fjord connected to Kalø Vig via a $400 \mathrm{~m}$ strait. Knebel Vig is wind protected and has a mean depth of 3 to $4 \mathrm{~m}$ and a mean salinity of $20 \mathrm{ppt}$ (Christiansen et al. 1981).

Four mesocosms with $0.1 \mathrm{~mm}$ thick polyethylene walls, each with a volume of $6 \mathrm{~m}^{3}(1.5 \mathrm{~m}$ diameter and $3 \mathrm{~m}$ deep), were fllled with fjord water by 2 SCUBA divers. The mesocosms were initially pulled down vertically to the sediment; they were then filled with fjord water, including an intact plankton community, by pulling the top part up through the water column. A weight ensured the bags to be stretched in the free water mass. The mesocosms were closed just above the sediment surface and fixed to a pontoon bridge at the top. Each mesocosm was immediately examined for larger zooplanktivore organisms, i.e. fish and jellyfish. To keep the mesocosm water in circulation, wind-driven mills, each connected to a flat-plated stirrer situated $1 \mathrm{~m}$ below the surface, were mounted in each mesocosm (Fig. 1). 
The set-up consisted of 2 control mesocosms with natural fjord water ( $\mathrm{Cl}$ and $\mathrm{CII}$ ) and 2 mesocosms with natural fjord water spiked with inorganic nutrients to enrich the phytoplankton community ( $\mathrm{NCI}$ and NCII).

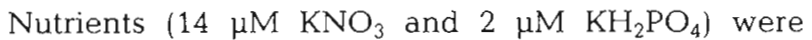
added every day.

The particle concentration of relevant food items with an equivalent spherical diameter of 2 to $20 \mu \mathrm{m}$ was measured in $20 \mu \mathrm{m}$ screened water samples from the 4 mesocosms as well as from the cove by an electronic particle counter (Sysmex F-800 modified by Merck) every other day. Three counts were made for each water sample, resulting in a mean variability among samples $(n=39)$ of $9.3 \%(\mathrm{SD}=7.4 \%)$. Due to this limited variability, the count closest to the mean value of the 3 counts was consequently selected to represent the particle content of a given water sample.

Polychaete larvae from each mesocosm were sampled regularly (every day for the control mesocosms and July 17, 18, 20, 22 and 26 and August 1 and 2 for the enriched mesocosms) by depth integrated water sampling. A $3 \mathrm{~m}$ long polypropylene tube equipped with an opening/closing device gave 121 sample $^{-1}$. Later in the study period it was necessary to repeat the water casts to get enough polychaete larvae (2 to 4 casts). To evaluate the sampling variability, 2 samples were taken successively on July 22 . The samples were gently filtered onto a submerged $45 \mu \mathrm{m}$ Nitex screen. The larvae were transferred to a $100 \mathrm{ml}$ container and immediately fixed in Carrikers solution ( $2 \%$ final concentration of formalin with borax and glucose in seawater) for later analysis.

To assess if the polychaetes settled at the sides of the mesocosms six $3 \mathrm{~m}$ long settling strips composed of the same material as the bags were mounted along the periphery in the mesocosms (see Stenalt et al. 1998). Every $5 \mathrm{~d}, 1$ settling strip was harvested in each mesocosm, rolled gently and fixed in a $500 \mathrm{ml}$ container with Carrikers solution. By vigorously shaking the container all the larvae on the strip would detach themselves and be able to be identified and counted. However, this method showed no settling at all. At the end of the experiment the abundance of settled polychaetes at the bottom of the mesocosms was monitored by cutting out 4 randomly chosen pieces of the polyethylene wall material (in total 440 to $745 \mathrm{~cm}^{2}$ ), which were then rolled and fixed in Carrikers solution (Hansen et al. 1997). Several months later all the settled polychaetes were identified and counted. Assuming an equal distribution of settled individuals over the entire bottom of the mesocosms, the total population was calculated by assuming the bottom substrate area in each mesocosm to be a cone (see Fig. 1). The natural instantaneous mortality for each polychaete larval/post-larval population was assumed to follow an exponential curve.
The instantaneous mortality rate $\left(k, \mathrm{~d}^{-1}\right)$ was calculated by the equation describing the relationship between the total abundance of individuals within the population at the start of the experiment $\left(N_{0}\right)$, equal to larval abundance $x$ volume of the mesocosm, and that at the end of the experiment $\left(N_{t}\right)$, equal to larval abundance $x$ volume of the mesocosm + abundance of settled individuals, following $N_{i}=N_{0} \times \mathrm{e}^{-k t}$, where $t$ was duration of the experiment (Hansen 1993).

Larval and settled polychaete identification was determined from Thorson (1946), Hannertz (1956), Rasmussen (1956, 1973), Blake (1969), Daro \& Polk (1973) and Plate \& Husemann (1994) and based upon morphology, pigmentation, number of setigers and body size.

Larval abundance was analysed in a dissecting microscope ( $n=100$ to 300 individual counted or as many as present in the sample). For counting larval segments, the first 25 Polydora spp. and Spio/Microspio spp. and 10 Nereis (Neanthes) succinea larvae from each sample were chosen. In the present study segmentation for a given larva was defined as including the tail and excluding the head. If any metamorphosed larvae were observed, it was noted and the species determined if possible. Unidentified larvae (of which there were very few) were excluded from the data material.

Larvae for analysis of body length and carbon were isolated from control and enriched mesocosms and pooled during the entire study period. Polydora spp. and Spio/Microspio spp. larvae were divided into groups defined by the number of body segments; for these species, each group spanned an intervals of 2 segments. Nereis (Neanthes) succinea larvae were divided into groups for each number of segments. Larvae ranging in body size from a few segments up to metamorphosis-competence were recorded by a CCDvideo camera (CV-730 JAI-Vision) mounted on a dissecting microscope at 10 to $40 \times$ magnification connected to a video recorder (Panasonic MV200 HQ SVHS). Body length of the larvae of each species was measured ( $n=3$ to 8 for Polydora spp. and Spiol Microspio spp; $\mathrm{n}=2$ to 13 for $N$. (Neanthes) succinea) by a computer based image analysis program (Mocha ver. 1.2, Jandel Scientific, CA, USA). The software defines larval length as the longest distance between 2 points (head and tail) given by the operator. Examples of length measurements of straightened as well as bent larvae are shown in Fig. 2.

After larval measurements the same individuals were washed in $0.2 \mu \mathrm{m}$ filtered seawater followed by glass distilled water and frozen in batches of 1 to 25 individuals in small $550^{\circ} \mathrm{C}$ pre-muffled aluminum bowls at $-80^{\circ} \mathrm{C}$. After drying for $2 \mathrm{~h}$ at $50^{\circ} \mathrm{C}$ the larval carbon content was determined by an infra-red gas analyzer (ADC $225 \mathrm{MK} 3$ ) equipped with a tube fur- 

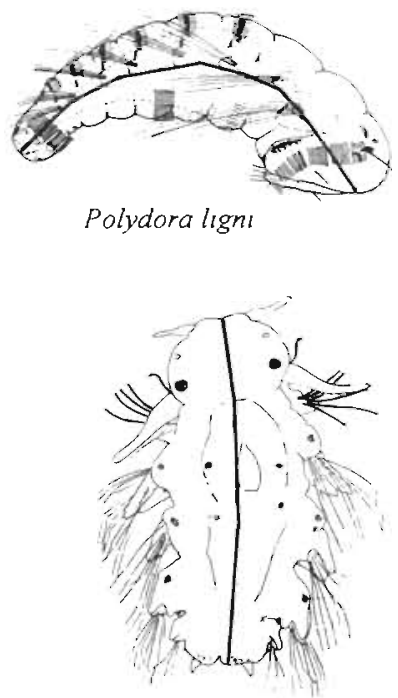

Nereis (Neanihes) succinea

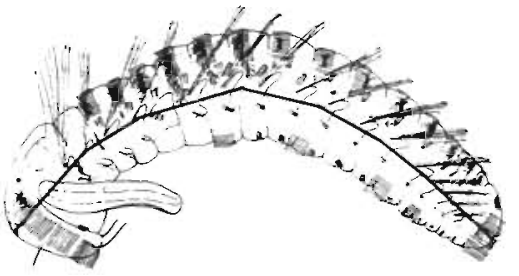

Polydora ligni

Fig. 2. Principle of length measurements on polychaete larvae with the image analysis software (Mocka ver. 1.2 Jandel Scientific). Larval segments were defined as including the tail and excluding the head. The thick solid line drawn onto each larvae is used to measure the body length. Drawings of larvae based on Banse (1954), Hannertz (1956) and Blake (1969)

nace (Hansen \& Ockelmann 1991) and converted to $\mu \mathrm{g}$ of carbon per individual.

Basic information like number of larval setigers versus body length, given as a linear regression (Bochert $\&$ Bick 1995), larval setigers versus carbon content, and body length versus carbon content, given as non-linear power functions (e.g. Anger et al. 1986), are presented by regression fits provided by SigmaStat (Jandel Scientific, CA, USA).

Specific growth rates $\left(G, \mathrm{~d}^{-1}\right)$ during the fast growth phase, defined as where the growth curves did not reach saturation (July 17 to 22) for Polydora spp. and Spio/Microspio spp. and as the entire growth period for Nereis (Neanthes) succinea, were calculated. These calculations were obtained from curve fits: $\ln W_{t 1}=\ln W_{10}+G \times$ $t$, where $W_{l 0}$ and $W_{l 1}$ are the mean individual carbon contents of larvae at a given time and after a time increment, respectively, and $t$ is the duration of the growth period. Significant differences between the slopes of linear regressions of ln-transformed data, representing the specific growth rates, were tested by a 2 -tailed $t$-test.

\section{RESULTS}

The entire study period was characterized by a high pressure situation with a mean wind speed of 2.5 to $6.9 \mathrm{~m} \mathrm{~s}^{-1}$ (average of $4.4 \mathrm{~m} \mathrm{~s}^{-1}$ ) and the water temperature was 21 to $23^{\circ} \mathrm{C}$. Between Days 9 and 15 one of the enriched mesocosms was damaged and became leaky. This was excluded from the experiment thereafter.

\section{Food availability}

The particle contents in the cove and in the control mesocosms were similar, and the bulk of the particle biovolume was within the range of 2 to $20 \mu \mathrm{m}$ (Fig. 3). In the enriched mesocosms the particle biovolume increased significantly in comparison to the control ( $t$-test $\mathrm{p}<0.05$ ) and especially in the ca $5 \mu \mathrm{m}$ fraction. The total mean $\pm \mathrm{SD}$ food availability in the control mesocosms during the study period was $3.12 \pm 0.62 \times 10^{6} \mu^{3}$ $\mathrm{ml}^{-1}$, corresponding to $582 \pm 109 \mu \mathrm{g}$ carbon $\mathrm{l}^{-1}$, and in the enriched mesocosms was $6.94 \pm 2.37 \times 10^{6} \mu \mathrm{m}^{3} \mathrm{ml}^{-1}$, corresponding to $1191 \pm 505 \mu \mathrm{g}$ carbon $\mathrm{l}^{-1}$ (for conversion to carbon see Stenalt et al. 1998). The calculated food availability based upon observed biovolume was not statistically different from results obtained by POC (particulate organic carbon) measurements ( $t$-test $\mathrm{p}>$ $0.05)$, and the biomass development over time showed the same pattern. In the control mesocosms the measured total mean \pm SD POC was $805 \pm 365 \mu \mathrm{g} \mathrm{Cl}^{-1}$ and in the enriched mesocosms was $1428 \pm 498 \mu \mathrm{g} \mathrm{C} \mathrm{I}^{-1}$. POC $<10 \mu \mathrm{m}$ in particle size accounted for 94 and $74 \%$. respectively. The $\mathrm{C}: \mathrm{N}$ ratio of the particular matter was $10.9 \pm 4.3$ in the controls and $9.1 \pm 4.5$ in the enriched bags, and these were not statistically different ( $t$-test $p>0.05$ ) (K. Christoffersen unpubl.). However, the food availability in the enriched bags was significantly higher than in controls ( $t$-test $p<0.05$ ).

\section{Polychaete larvae}

The polychaete larval community consisted of Polydora spp. (a mixture of $P$. ciliata Johnson \& $P$. ligni Webster), Spio/Microspio spp. (probably $M$. cf. atlantica Langerhans) and Nereis (Neanthes) succinea Fry \& Leuchard (Fig. 2). The variation between larval abundance from 2 replicate samplings taken in a con-

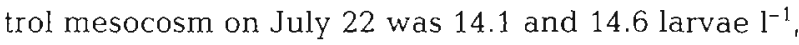
revealing good sampling reproducibility. The difference in larval abundance between replicate mesocosms was never higher than $25 \%$.

Polychaete larval abundance in control mesocosms was approximately $15 \mathrm{l}^{-1}$; this value declined after the first week and was eventually $<1 I^{-1}$ at the end of the 


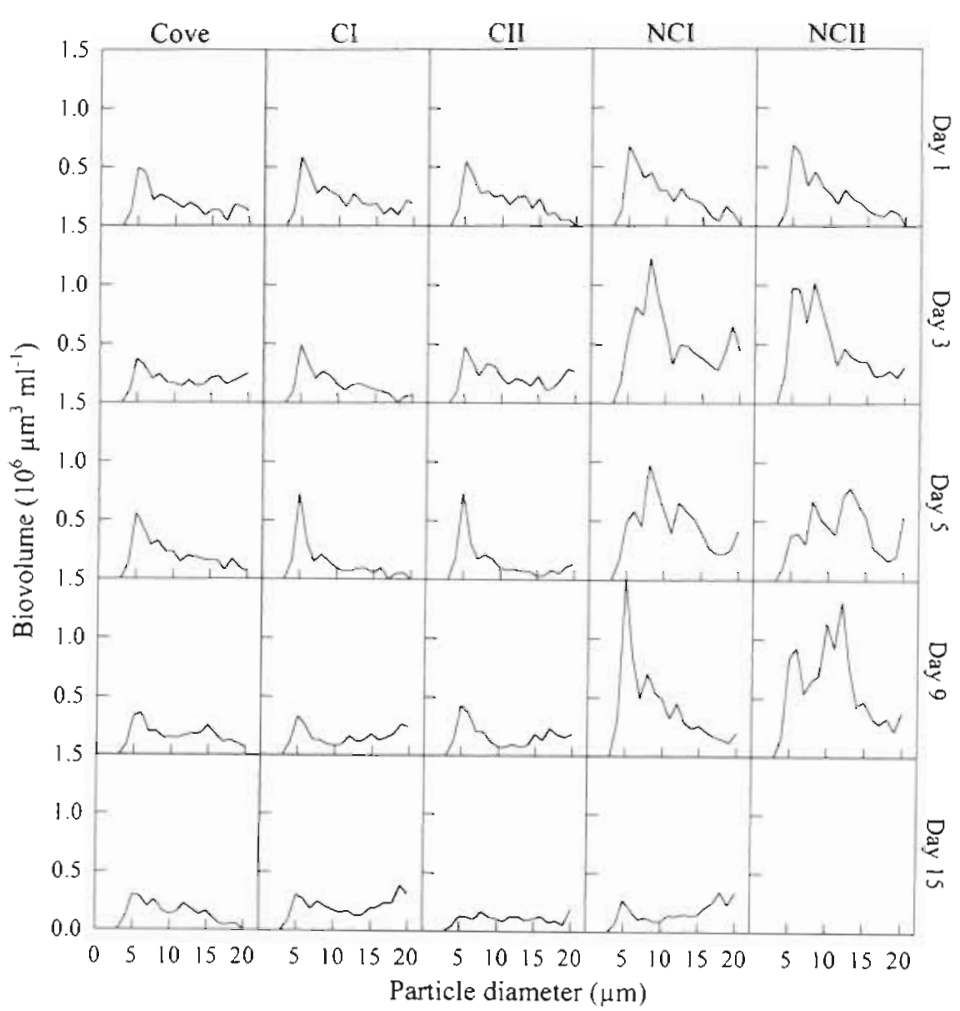

Fig. 3. Biovolume of potential food particles in the cove, in the control mesocosms with fjord water (CI and $\mathrm{CII})$ and in the mesocosms with fjord water enriched with inorganic nutrients (NCI and NCII)

study period (Fig. 4). In the enriched mesocosms the larval cohorts were initially present in the same abundance as in the controls, but the abundance declined faster (Fig. 4).

The relative composition of the polychaete larval community revealed that Polydora spp. was generally the dominating species followed by Spio/ Microspio spp., which accounted for $<25 \%$ of the total larval abundance. Nereis (Neanthes) succinea was present with an abundance similar to Spio/Microspio spp. Polydora spp. abundance declined most rapidly in both control and enriched mesocosms, and at the end virtually only N. (Neanthes) succinea was present in the water column (August 1 and 2: $<1$ larvae $1^{-1}$ ).

Polychaete larvae competent to metamorphose were occasionally observed in the free water mass of the mesocosms. In the controls the following numbers per sample were identified: on July 22, 3 metamorphosed Polydora spp., on July 26, 3 metamorphosed Nereis (Neanthes) succinea (both representing $<4 \%$ of the total pelagic cohort abundance), and, on August 1, 8 metamorphosed Polydora spp. (representing $67 \%$ of the pelagic cohort). In the enriched mesocosms, metamorphosed Spio/Microspio spp. were found on July 22 ( $n=1$ sample s $^{-1}$ equals $5 \%$ of the cohort), on July 26 ( $n=7$ sample $^{-1}$ equals $47 \%$ of the cohort) and on August 1 ( $n=2$ sample $^{-1}$ equals $66 \%$ of the cohort).

The individual larvae in the cohorts increased in mean setiger number from 7 to 16 for Polydora spp. and from 6 to $15-17$ for Spio/Microspio spp. and had a growth saturation curve with a fast growth phase from July 17 to 22 followed by a stationary phase. During the fast growth phase the setiger increase was 1.49 to 1.83 and 0.98 to $1.71 \mathrm{~d}^{-1}$ for the 2 species, respectively. Nereis (Neanthes) succinea continued to increase in setiger number from 3 to $8-9$ during the entire study period, with a daily setiger increase of 0.05 to 0.18 (Fig. 5). No difference in setiger increments between controls and enriched mesocosms was observed for Polydora spp. ( $t$-test $p>$ 0.05 ), but the mean setiger numbers seemed to diverge after July 22 for the other 2 larval species, though not significantly

The mean larval bady length increase showed the same pattern as the setiger number increase (Fig. 6); Polydora spp, reached approximately $1000 \mu \mathrm{m}$ in body length with an increase of 96.9 to $119.0 \mu \mathrm{m} \mathrm{d}^{-1}$ independent of food availability,

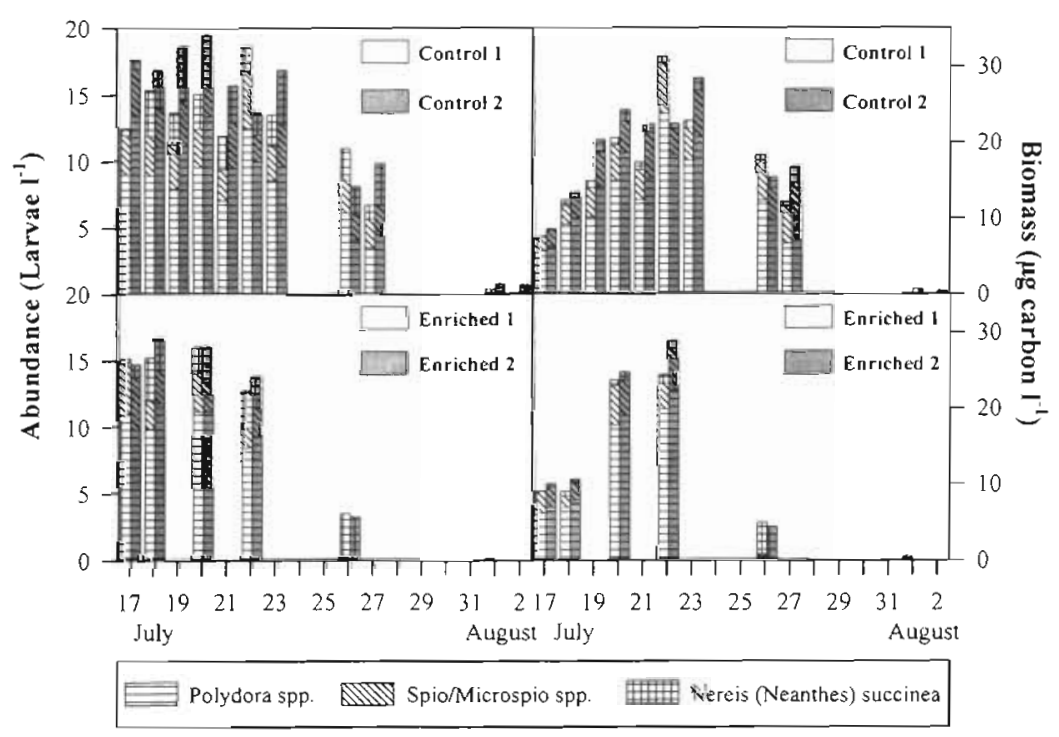

Fig. 4. Abundance and biomass of polychaete larvae in the control mesocosms with fjord water and in the mesocosms with fjord water enriched with inorganic nutrients 


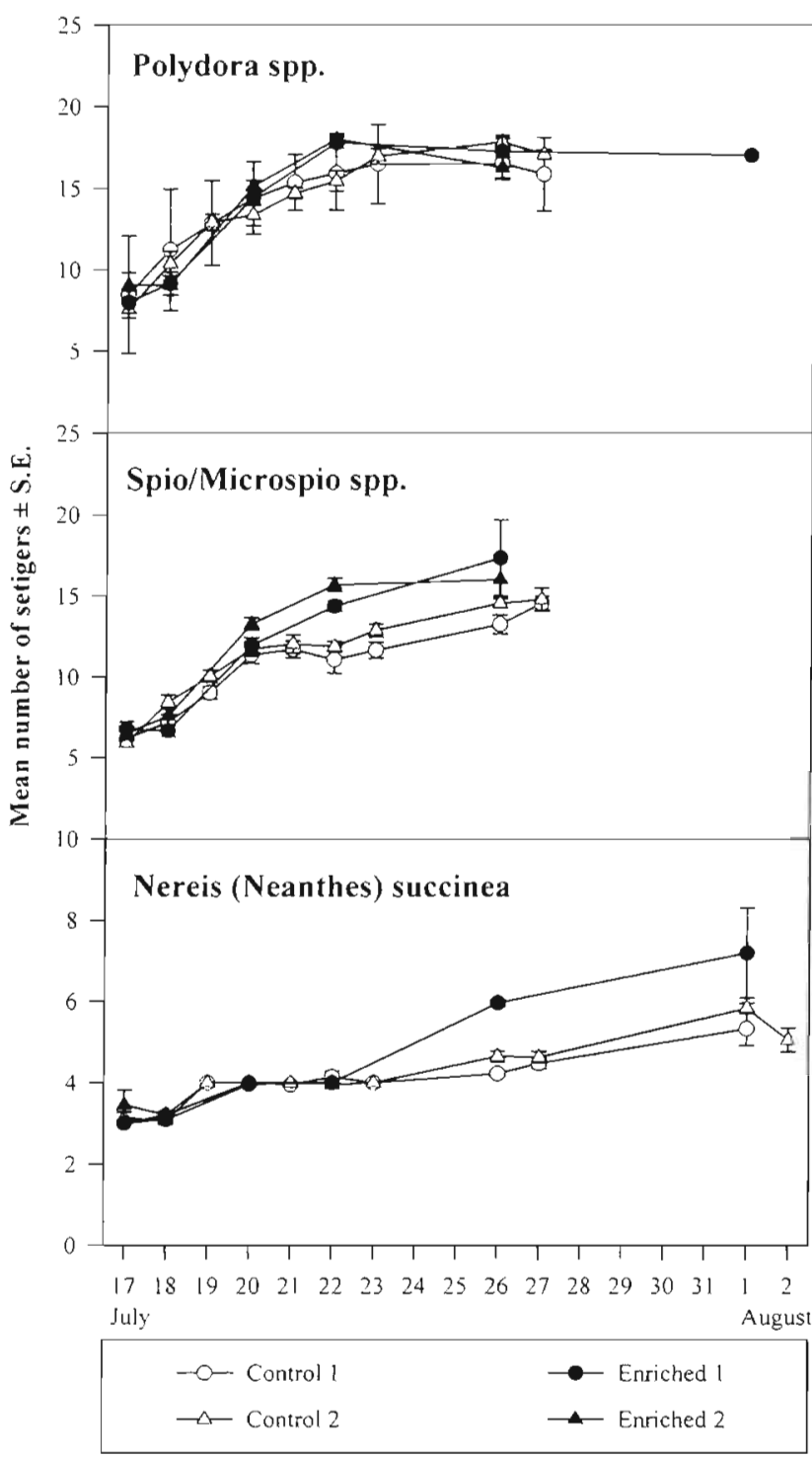

Fig. 5. Growth of polychaete larvae in terms of mean $\pm \mathrm{SE}$ setiger increments over time in the control mesocosms with fjord water and in the mesocosms with fjord water enriched with inorganic nutrients

Spio/Microspio spp. obtained ca $720 \mu \mathrm{m}$ in the control mesocosm but $850 \mu \mathrm{m}$ in the enriched mesocosms with a daily increase of 53.5 to $223.8 \mu \mathrm{m}$, and Nereis (Neanthes) succinea continued to grow in length up to 450 and $700 \mu \mathrm{m}$ in the control and the enriched mesocosms, respectively, with a daily increase of 7.7 to $35.3 \mu \mathrm{m}$.

In order to describe growth in terms of segments, larval length and larval carbon content simple relations are showed in Fig. 7 for all 3 species of larvae covering their entire larval life from emergence in the pelagic as segmented, planktotrophic larvae until time of metamorphosis. These equations are meant as tools for ecol-

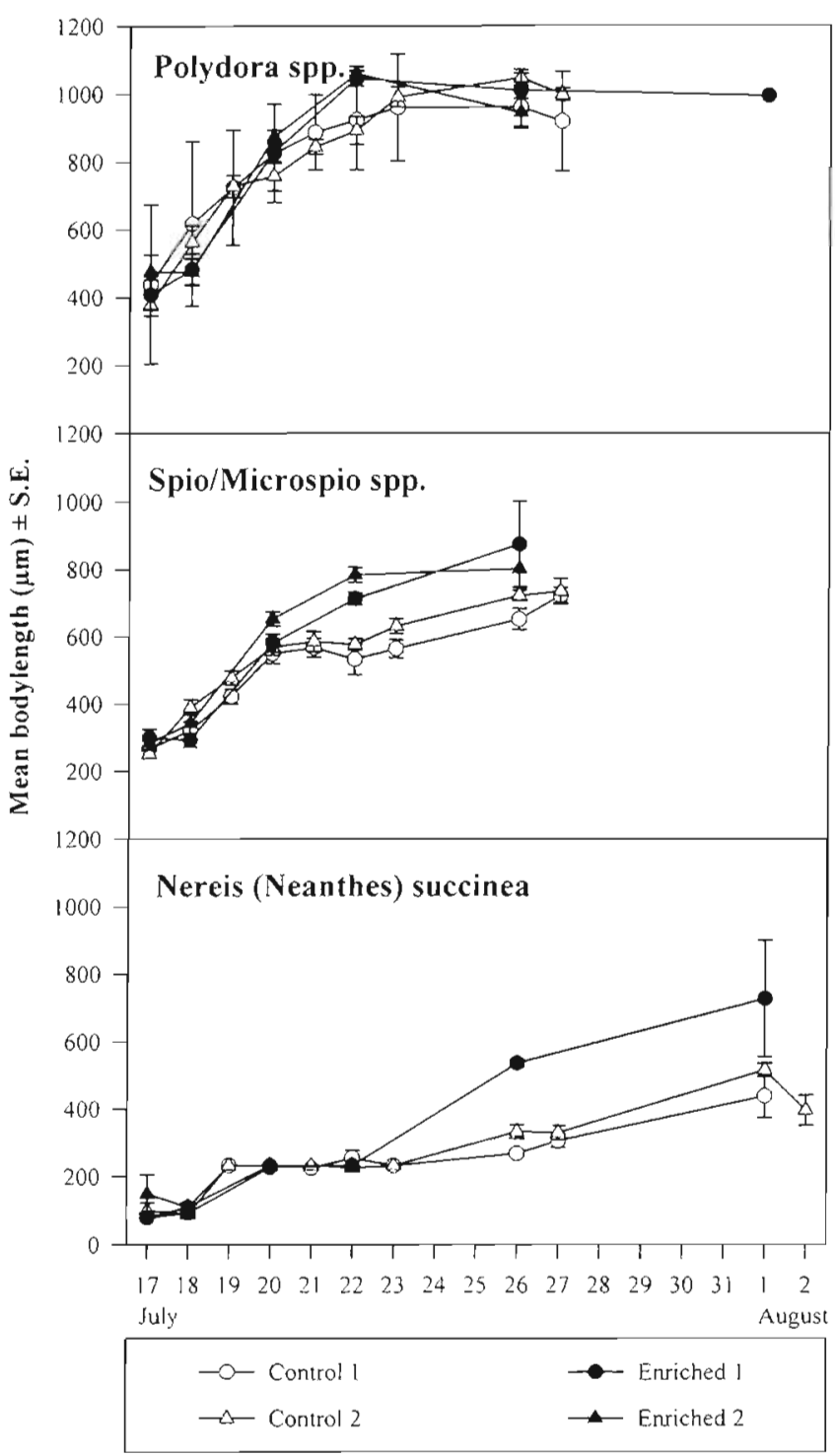

Fig. 6. Growth of polychaete larvae in terms of mean \pm SE body length increments over time in the control mesocosms with fjord water and in the mesocosins with fjord water enriched with inorganic nutrients

ogists wanting to quantify the biomass of polychaete larvae in zooplankton samples. All curve fits are characterised by a very high $\mathrm{R}^{2}$. The individual larval length versus carbon content regressions revealed a slope of 1.38 for Polydora spp., 1.79 for Spio/Microspio spp. and 1.47 for Nereis (Neanthes) succinea, reflecting the fact that their morphometrics became more and more elongated (Table 1).

Larval growth in terms of increase in individual carbon content (Fig. 8) was used for calculating specific growth. In Table 2 the specific growth rates $(G)$ of Polydora spp. and Spio/Microspio spp. in the fast growth phase were not significantly different between control 
Table 1. Fitted models for larval length $(L)$ vs setiger number $(S)$, carbon content $(C)$ vs setiger number and carbon content vs body length for Polydora spp., Spio/Microspio spp. and Nereis (Neanthes) succinea

\begin{tabular}{|ccc|}
\hline Parameter Polydora spp. & Spio/Microspio spp. & Nereis (Neanthes) succinea \\
\hline $\begin{array}{c}\text { Body length }(\boldsymbol{\mu m}) \text { vs number of setigers } \\
L=65.13 \pm 5.70 \times S-113.20 \pm 70.56\end{array}$ & $L=54.51 \pm 4.82 \times S-70.32 \pm 65.23$ & $L=154.4 \pm 10.4 \times S-384.9 \pm 59.7$ \\
$\mathrm{R}^{2}=0.745$ & $\mathrm{R}^{2}=0.729$ & $\mathrm{R}^{2}=0.832$ \\
Carbon content $(\boldsymbol{\mu g})$ vs number of setigers & & \\
$C=6.81 \times 10^{-3} \pm 4.14 \times 10^{-3} \times S^{203 \pm 0.22} C=3.84 \times 10^{-2} \pm 2.34 \times 10^{-2} \times S^{153 \pm 0.22}$ & $C=6.23 \times 10^{-3} \pm 1.34 \times 10^{-3} \times S^{2.99 \pm 0.10}$ \\
$\mathrm{R}^{2}=0.990$ & $\mathrm{R}^{2}=0.986$ & $\mathrm{R}^{2}=0.985$ \\
Carbon content $(\boldsymbol{\mu g})$ vs body length $(\mu \mathrm{\mu m})$ & & $C=1.42 \times 10^{-4} \pm 8.05 \times 10^{-5} \times L^{147 \pm 0.08}$ \\
$C=1.58 \times 10^{-4} \pm 2.18 \times 10^{-4} \times L^{1.38 \pm 020}$ & $C=1.34 \times 10^{-5} \pm 2.24 \times 10^{-5} \times L^{1.79 \pm 0.24}$ & $\mathrm{R}^{2}=0.993$ \\
$\mathrm{R}^{2}=0.996$ & $\mathrm{R}^{2}=0.998$ & \\
\hline
\end{tabular}
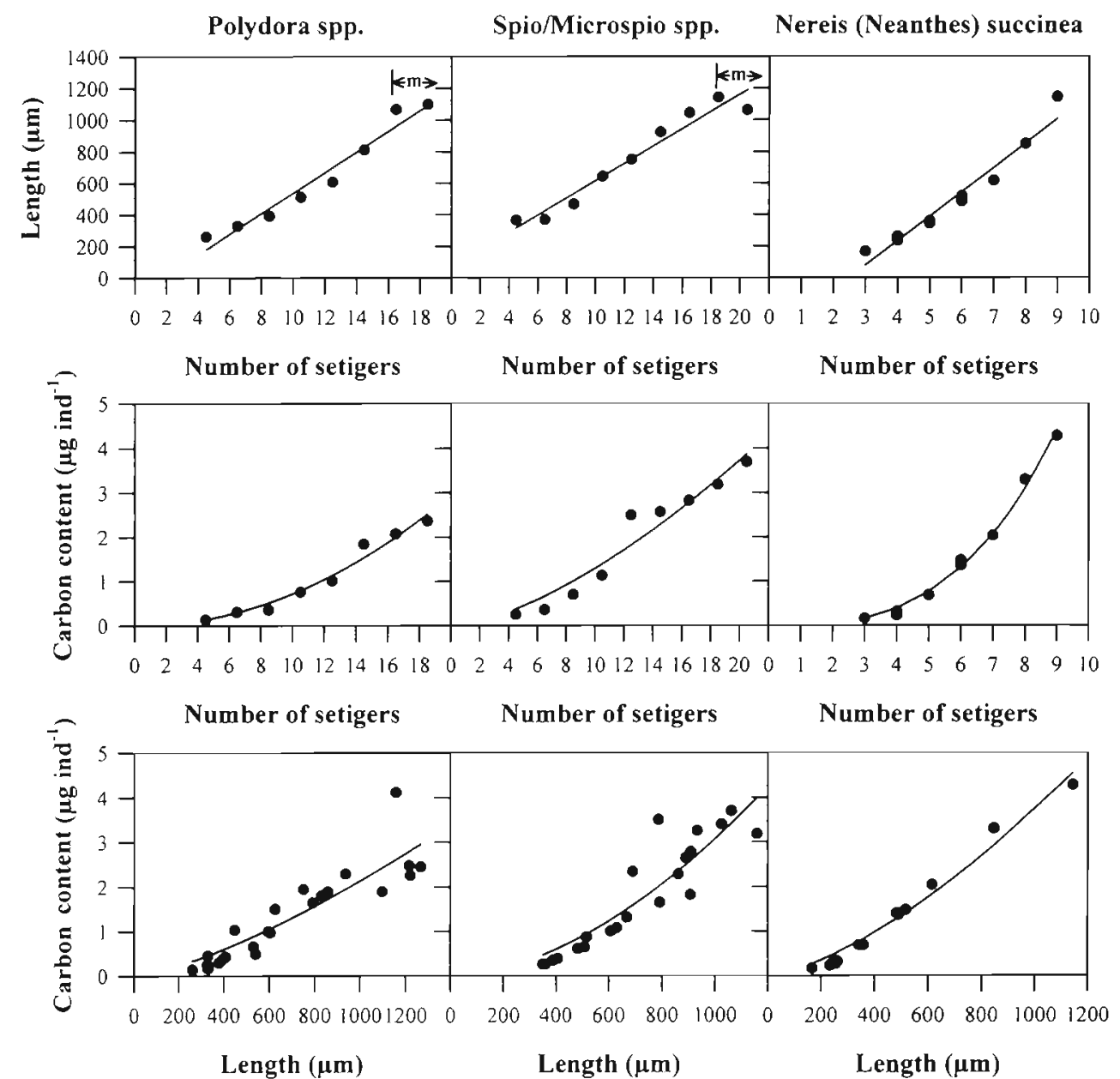

Fig. 7. Relationships between polychaete larval setiger number vs body length, setiger number vs individual carbon content and body length vs individual carbon content. m: metamorphosis

and enriched mesocosms ( $t$-test $\mathrm{p}>0.05)$. For Nereis (Neanthes) succinea, however, the specific growth rate in 1 of the enriched mesocosms was higher than in the controls ( $t$-test $\mathrm{p}<0.01$ ).
The calculated total larval biomass of the polychaete species in the mesocosms revealed that the populations increased from approximately 7 to $30 \mu \mathrm{g} \mathrm{C}^{-1}$ in both situations (Fig. 4), whereafter the biomass de- 


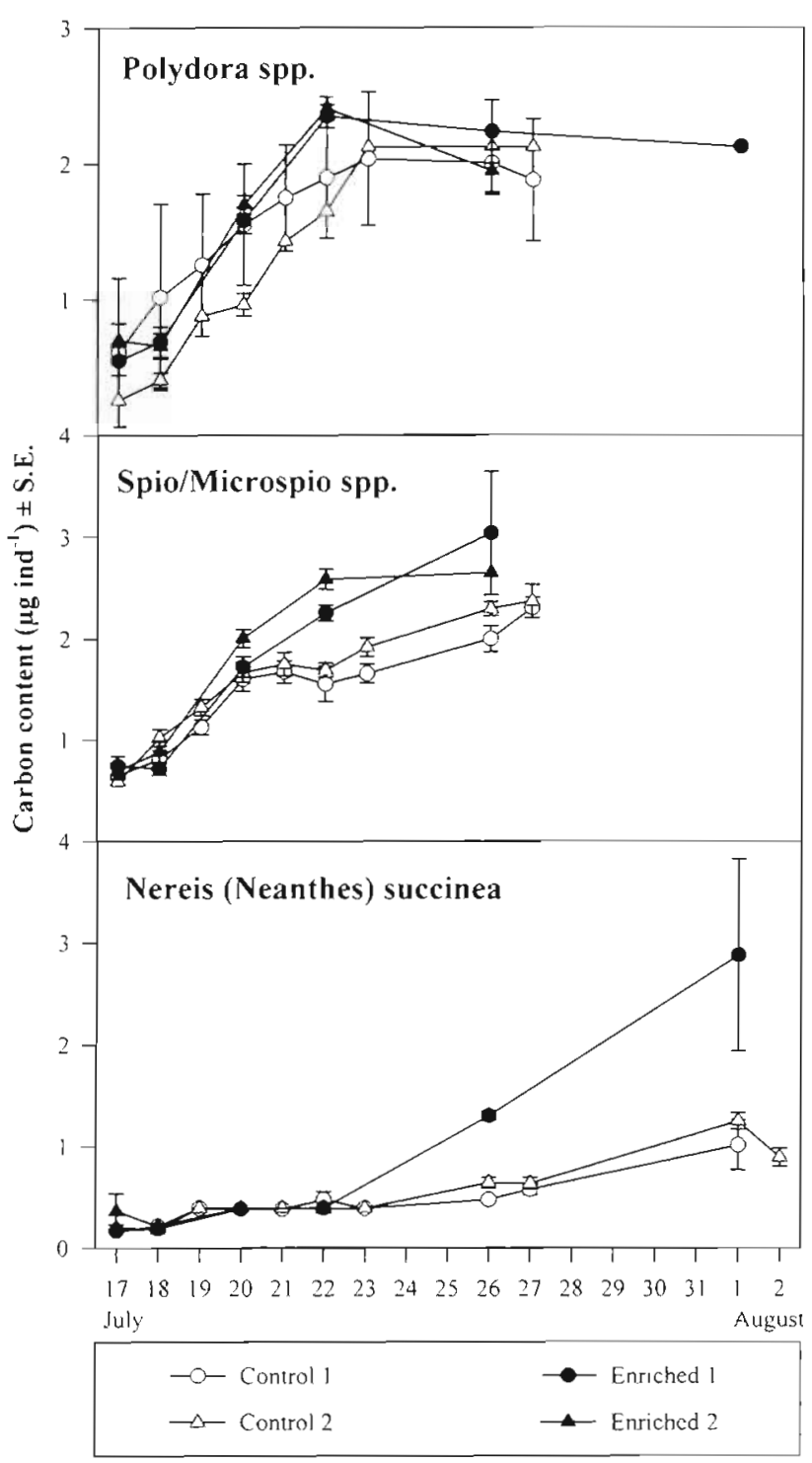

Fig. 8. Growth of the polychaete larvae in terms of mean \pm SE individual carbon content in the control mesocosms with fjord water and in the mesocosms with fjord water enriched with inorganic nutrients

clined. The biomass decline was most pronounced in the enriched mesocosms due to faster development towards metamorphosis, and reached virtually zero at the end of the experiment.

\section{Settled polychaetes and populational instantaneous mortality}

The estimated number of settled polychaetes was highest in the control mesocosms where $>6000$ and $>10000$ Polydora spp. as well as ca 1600 and 2300
Spio/Microspio spp. were identified, whereas only 29 and 193 Nereis (Neanthes) succinea were found in CI and CII, respectively. Opposite results were obtained from the enriched mesocosm, where only $N$. (Neanthes) succinea was present and neither of the other 2 polychaete species was found (Fig. 9).

The fraction of the initial polychaete larval populations which survived in $\mathrm{CI}, \mathrm{CII}$ and $\mathrm{NCI}$ after the experimental period of $16 \mathrm{~d}$ is listed in Table 2 . The mean \pm SE estimated instantaneous mortality rates for the 3 species were $0.16 \pm 0.04$ and $0.37 \pm 0.15 \mathrm{~d}^{-1}$ for the controls and the enriched mesocosms, respectively.

\section{DISCUSSION}

The mesocosm experiment and the collection of larvae took place from mid July until the beginning of August. Planktonic stages of Polydora ciliata are known from all months of the year in Danish waters (Thorson 1946, Rasmussen 1973), while Spio martinensis and Microspio atlantica occur most of the summer (Hannertz 1956, Plate \& Husemann 1994) and Nereis (Neanthes) succinea spawn from May to October in Danish waters (Kirkegaard 1992). So, according to the literature, the period of the present study was well within the planktonic phase of all 3 species of planktotrophic larvae. The experiment enabled the collection of relatively distinct cohorts of all 3 species of larvae in the mesocosms in mid July, making it possible to follow their development until metamorphosis. Therefore, the mesocosm concept was a useful tool for this particular purpose.

The observed disappearance of polychaete larvae from the pelagic during July can be attributed to mortality or settling (e.g. Hansen et al. 1997). Since no reduction in larval abundance was observed during the first week (Fig. 4), mortality is not believed to be a major loss for these pelagic cohorts initially. Settling and mortality were not measured continuously during the experiment since the polychaetes did not settle on streamers hanging in the water column in the mesocosms, as recently demonstrated for bivalve larvae (see Hansen et al. 1997, Stenalt et al. 1998). According to the ratio of metamorphosed larvae versus pelagic larvae (see 'Results'), a clear progression was observed as the experiment continued. These metamorphosed polychaetes were tentatively present in the water column. Larval development beyond competence for metamorphosis as an explanation of their disappearance from the pelagic is further supported by the observation that Polydora spp. and Spio/Microspio spp. larvae had reached their maximum setiger numbers after $1 \mathrm{wk}$ of the experiment (Fig. 5). However, Nereis (Neanthes) succinea was still present as larvae 
Table 2. Survival and instantaneous mortality rate for the entire study period, and mean \pm SE specific growth rates $\left(\ln W_{t 1}=\ln W_{t 0}\right.$ $+G \times t_{i}$ see text) of cohorts of Polydora spp. and Spio/Microspio spp. larvae during the fast growth phase and Nereis (Neanthes) succinea during the entire study period in control mesocosms with natural fjord water and nutrient enriched fjord water, Knebel Vig, 1995. n: number of data points included in $G$. Two-tailed $t$-test upon the slopes of In-transformed data was performed for determination of significantly different $G$ between the 2 treatments. nd: not determined. -: no significance; ${ }^{*} p<0.01$

\begin{tabular}{|c|c|c|c|c|c|}
\hline Species of larvae & $\begin{array}{c}\text { Survival } \\
\text { (\% of initial) }\end{array}$ & $\begin{array}{l}\text { Instantaneous } \\
\text { mortality }\left(\mathrm{d}^{-1}\right)\end{array}$ & $\begin{array}{c}G\left(\mathrm{~d}^{-1}\right) \\
(\text { mean } \pm \mathrm{SE})\end{array}$ & $\mathrm{p}$ & $\mathrm{n}$ \\
\hline \multicolumn{6}{|l|}{ Polydora spp. } \\
\hline Control 1 & 13.1 & 0.13 & $0.21 \pm 0.04$ & - & 6 \\
\hline Control 2 & 13.8 & 0.12 & $0.25 \pm 0.05$ & - & 6 \\
\hline Enriched 1 & 0.3 & 0.39 & $0.31 \pm 0.03$ & - & 4 \\
\hline Enriched 2 & nd & nd & $0.28 \pm 0.06$ & - & 4 \\
\hline \multicolumn{6}{|c|}{ Spio/Microspio spp. } \\
\hline Control 1 & 9.9 & 0.15 & $0.20 \pm 0.04$ & - & 6 \\
\hline Control 2 & 16.2 & 0.11 & $0.20 \pm 0.05$ & - & 6 \\
\hline Enriched 1 & 0.0 & 0.67 & $0.25 \pm 0.05$ & - & 4 \\
\hline Enriched 2 & nd & nd & $0.28 \pm 0.04$ & - & 4 \\
\hline \multicolumn{6}{|c|}{ Nereis (Neanthes) succinea } \\
\hline Control 1 & 0.2 & 0.38 & $0.15 \pm 0.03$ & & 10 \\
\hline Control 2 & 27.4 & 0.08 & $0.16 \pm 0.02$ & - & 11 \\
\hline Enriched 1 & 49.7 & 0.05 & $0.31 \pm 0.04$ & $\cdot$ & 6 \\
\hline Enriched 2 & nd & nd & $0.19 \pm 0.08$ & - & 5 \\
\hline
\end{tabular}

at the end of the study and was still increasing in setiger number. Settling did actually occur at the bottom of the mesocosms where organic sediment had accumulated during the experiment. After the pelagic phase, the polychaete larvae chose to settle on the bottom of the mesocosms and Polydora spp. and Spio/Microspio spp. built their tubes. However, the load of sedimented material probably caused low oxygen content and presumably not a favourable habitat. Hence, the post larvae might have suffered mortality especially in the enriched mesocosms during the phase when they change from pelagic to benthic living (Wang \& Widdows 1991). Additionally, N. (Neanthes) succinea was found as benthic stages of 1.5 to $2 \mathrm{~mm}$ in length especially in the enriched mesocosm, but none of the more sedentary species were present. This could be due to $N$. (Neanthes) succinea larvae growing faster in the enriched mesocosms and despite the conditions being able to settle.

The instantaneous mortality rate, calculated as a constant rate from July 17 to August 2, was 0.05 to $0.39 \mathrm{~d}^{-1}$, which is within the range reported for bivalve, bryozoan and cirriped larvae monitored on natural cohorts (Rumrill 1990), and for bivalve larvae in mesocosms (Hansen et al. 1997, Stenalt et al. 1998). But since predation is considered to be the most important source of larval mortality in situ (Morgan 1995), and it was attempted to eliminate this factor in the present study by removing visible predators, a lower mortality was expected. However, the mortality estimates were based upon several assumptions, e.g. exponential decrease from the beginning of the experiment, even dis- tribution of settled polychaetes on the bottom of the mesocosms, and a roughly calculated bottom area. In conclusion, despite these uncertainties the mortality estimates gave reasonable values and the methodology therefore is encouraging and should be developed further.

The food availability in the control mesocosms was as in situ, which is why the potential for development and growth of the larvae resemble what is to be expected in the cove. The addition of inorganic nutrients stimulated the primary producers, especially in the $5 \mu \mathrm{m}$ size class. This increase was due to a bloom of the cryptophyte Hemiselmis virescens (G. Hansen \& B. Riemann unpubl.) which is expected to be within the

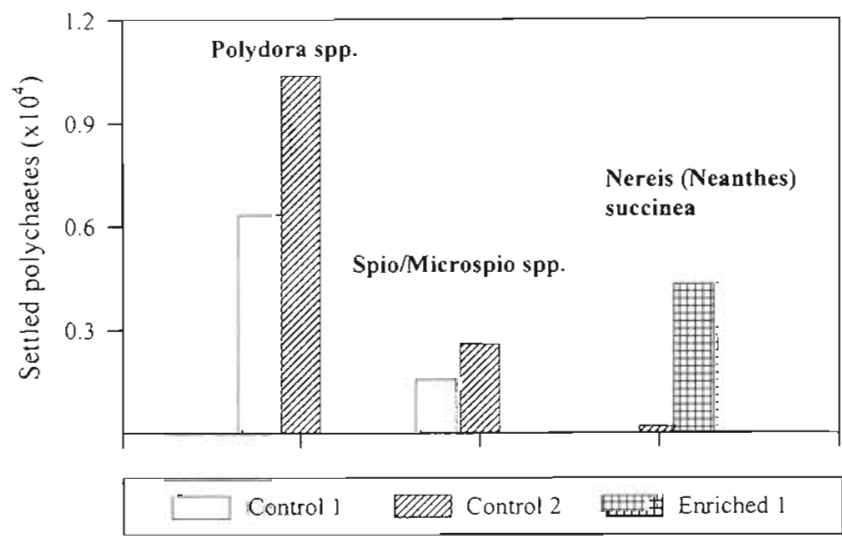

Fig. 9. Number of settled polychaetes after $16 \mathrm{~d}$ in the experiment in the control mesocosms with fjord water and in 1 of the mesocosms with fjord water enriched with inorganic nutrients 
retention spectra of spionid polychaete larvae (Daro \& Polk 1973, Anger et al. 1986). However, the food availability in the enriched mesocosms was significantly higher than in controls.

Developmental time for polychaete larvae in the mesocosms, 12 to $13 \mathrm{~d}$, equalled that reported for wellfed Polydora spp. in culture (Anger et al. 1986). Additionally, these larvae did not develop faster when offered a higher food concentration in the enriched mesocosms. The maximum growth of Polydora spp. was reported to be 1.93 segments $\mathrm{d}^{-1}$ (Anger et al. 1986), for 3 to 9 segment larvae of $P$. ciliata 2 segments $\mathrm{d}^{-1}$, and from 9 segments and onwards 1 segment $\mathrm{d}^{-1}$ (Daro \& Polk 1973). In the present study 1.6 segments $\mathrm{d}^{-1}$ was observed for the fast growth phase ( 7 to $17 \mathrm{seg}$ ments) (Fig. 5), revealing a comparable and possible maximum growth. Food particles $>20 \mu \mathrm{m}$ were not quantified and if these food particles were of relevance for Polydora spp. as suggested by Daro \& Polk (1973) my description of food availability is incomplete. But no difference in growth was observed when elevated food levels were made available, which indicates that this was not the case. When larvae of P. ligni were starved for 1 to $3 \mathrm{wk}$, growth was reported to be retarded. But mortality was not significantly different from control larvae fed $11 \mathrm{mg} \mathrm{C} \mathrm{l}^{-1}$ of natural concentrated phytoplankton, and larval carbon content did not decrease significantly throughout 3 wk of starvation (Qian \& Chia 1993). This suggests that Polydora spp. larvae are rather robust and not very vulnerable to fluctuations in food availability.

Few specific growth rates for polychaete larvae have been reported in the literature. If nitrogen is the limiting factor for larval growth, as indicated by Anderson \& Hessen (1995) for copepods and by Marsh et al. (1989) for juvenile polychaetes, an analysis would be relevant. The ratio between dry weight and $\mathrm{N}$ is suggested to be 0.08 (Tenore \& Chesney 1985) and, assuming carbon:dry weight $=0.5$, the larval carbon:nitrogen $=6.25$. From the $\mathrm{C}: \mathrm{N}$ ratio given for the particular matter in the mesocosms it is possible to re-calculate all food availability data and relate them to observed growth. However, to my knowledge grazing and growth within meroplankton have not been reported in relation to available PON (particulate organic nitrogen) in the literature. The present observations of $G=0.21$ to 0.31 and 0.20 to $0.28 \mathrm{~d}^{-1}$ for Polydora spp. and Spio/Microspio spp. (Table 2) are comparable with those reported for $P$. ligni and $P$. ciliata in culture (Anger et al. 1986). Mean specific growth rates $(G)$ during the fast growth phase (Table 2) indicated, although not statistically significant, an elevated mean value for Spio/Microspio spp. The continuous growth by Nereis (Neanthes) succinea was significantly elevated when higher food availability was present in 1 of the mesocosms. The observed variability of body size among individuals in the cohorts blurs the picture. Hence, more individuals are required to obtain statistically solid data in future studies. Pauley et al. (1985) reported that the trochophore of Serpula vermicularis appeared to have been food limited when offered natural plankton $\left(2.5 \mathrm{Hg} \mathrm{l}^{-1}\right.$ chlorophyll a [chl a] equal to $>100 \mu \mathrm{C} \mathrm{C} \mathrm{l}^{-1}$ when assuming a $\mathrm{C}$ :chl a ratio of 50 ) in comparison to enhanced food suspension (12 $\mu \mathrm{g} \mathrm{chl} \mathrm{a=}$ $600 \mu \mathrm{g} \mathrm{C} \mathrm{l}^{-1}$ ). Despite a very high natural food concentration in the control mesocosms, the enrichment with inorganic nutrients presumably also had an effect in the present study. This might be due to the higher biochemical quality of the food particles from a higher growth rate of the phytoplankters (G. Hansen \& B. Riemann unpubl.) and, although not significant, a higher mean nitrogen content. In the literature several authors emphasize that chlorophyll concentration is not a proper unit to measure food availability for meroplankton (e.g. Olson et al. 1987). The observed food limitation is often due to a mis-match between particle size distribution and the retention abilities of the grazer (Hansen 1993, Hansen et al. 1994). Even though I have documented the particle biovolume to be within the retention spectra of the grazers in the present study, and this was well above expected saturation levels for growth, this presumably could not sustain maximum growth. Therefore, some polychaete larval species tended to experience functional food limitation in their development and growth. Food limited growth inevitably leads to longer pelagic phases and thereby increased loss due to predation from zooplanktivore zooplankton and fish and a minor contribution of recruits to the benthic community.

Acknowledgements. Thanks are due to K. W. Ockelmann for help with larval identification and to $B$. Johansen and $E$. Stenalt for technical assistance. Thanks also to $\mathrm{S}$. von Lillienskjold for electronic particle counting and to $\mathrm{T} W$. Moller for creative and artistic graphics. This study was supported partly by Strategic Environmental Research Programme project no. 92.01.014.6.10-5.5 and by Danish National Science Council project no. 9502163. Image analysis software was supported by Danish National Science Council project no. 110954 to $\mathrm{O}$. Andersen.

\section{LITERATURE CITED}

Anderson TR, Hessen DO (1995) Carbon or nitrogen in marine copepods? J Plankton Res 17:317-331

Anger K, Anger V, Hagmeier E (1986) Laboratory studies of larval growth of Polydora ligni, Polydora ciliata, and Pygospio elegans (Polychaeta, Spionidae). Helgoländer Meeresunters 40:377-395

Baldwin BS, Newell IE (1995) Feeding rate responses of oyster larvae (Crassostrea virginica) to seston quantity and composition. J Exp Mar Biol Ecol 189:77-91

Banse K (1954) Über Morphologie und Larvalentwicklung 
von Nereis (Neanthes) succinea (Leuckart) 1847. Zool Jb (Anatomie) $74(1): 160-171$

Blake JA (1969) Reproduction and larval development of Polydora from northern New England (Polychaeta: Spionidae). Ophelia 7:1-63

Bochert R, Bick A (1995) Reproduction and larval development of Marenzelleria viridis (Verril, 1973) (Polychaeta, Spionidae). Mar Biol 123:763-773

Bochert R, Fritzsche D, Burckhardt R (1996a) Influence of salinity and temperature on growth and survival of the planktonic larvae of Marenzelleria viridis (Polychaeta, Spionidae). J Plankton Res 18:1239-1251

Bochert R, Zettler ML, Bochert A (1996b) Variation in the reproductive status, larval occurrence and recruitment in an estuarine population of Marenzelleria viridis (Polychaeta, Spionidae). Ophelia 45:127-142

Christiansen C, Christoffersen H, Schultz KE (1981) Hydrography, sediments and sedimentation in a low energy embayment, Knebel Vig, Denmark. Geogr Annlr 63A: 95-104

Daro HM, Polk P (1973) The autecology of Polydora ciliata along the Belgian coast. Neth J Sea Res 6:130-140

Eckert GL (1995) A novel larval feeding strategy of the tropical sand dollar, Encope michelini (Agassiz): adaptation to food limitation and an evolutionary link between planktotrophy and lecitotrophy. J Exp Mar Biol Ecol 187: $103-128$

Fenaux L, Strathmann MF, Strathmann RR (1994) Five tests of food-limited growth of larvae in coastal waters by comparisons of rates of development and form of echinoplutei. Limnol Oceanogr 39:84-98

Fotel FL, Jensen NJ, Wittrup L, Hansen BW (1999) In situ and laboratory growth by a population of blue mussel larvae (Mytilus edulis L.) from a Danish embayment, Knebel Vig. J Exp Mar Biol Ecol 233:213-230

George JD (1966) Reproduction and early development of the spionid polychaete, Scolecolepides viridis (Verril). Biol Bull 1:76-93

Hannertz L (1956) Larval development of the polychaete families Spionidae Sars, Disomidae Mesnil, and Poecilochaetidae N. Fam. in the Gullmar Fjord (Sweden). Zool Bidrag, Uppsala 31:1-204

Hansen B (1993) Aspects of feeding, growth and stage development by trochophora larvae of the polychaete Mediomastus fragile (Rasmussen) (Capitellidae). J Exp Mar Biol Ecol 166:273-288

Hansen B, Ockelmann K (1991) Feeding behaviour in larvae of the opistobranch Philine aperta. I. Growth and functional response at different developmental stages. Mar Biol 111:255-261

Hansen B, Hansen PJ, Bjørnsen PK (1994) The size ratio between planktonic predators and their prey. Limnol Oceanogr 39:395-403

Hansen B, Fotel FL, Jensen NJ, Wittrup L (1997) Physiological effects of the detergent linear alkylbenzene sulphonate on blue mussel larvae (Mytilus edulis) in laboratory and mesocosm experiments. Mar Biol 128:627-637

Jørgensen CB (1981) Mortality, growth, and grazing impact of a cohort of bivalve larvae, Mytilus edulis L. Ophelia 20: $185-192$

Kirkegaard JB (1992) Havbørsteorme. I. Errantia. Danmarks

Editorial responsibility: Otto Kinne (Editor),

Oldendorf/Luhe, Germany
Fauna 83. Dansk Naturhistorisk Forening, Copenhagen (in Danish)

Marsh AG, Grémare A, Tenore KR (1989) Effect of food type and ration on growth of juvenile Capitella sp. I (Annelida: Polychaeta): macro- and micronutrients. Mar Biol 102 : 519-527

Metaxas A, Young CM (1998) Responses of echinoid larvae to food patches of different algal densities. Mar Biol 130: 433-445

Morgan SG (1995) Life and death in the plankton: larval mortality and adaptation. In: McEdward L (ed) Ecology of marine invertebrate larvae. CRS Press Inc, New York, p 279-321

Olson RR, Olson MH (1989) Food limitation of planktotrophic marine invertebrate larvae: does it control recruitment success? Annu Rev Ecol Syst 20:225-247

Olson RR, Bosch I, Pearse JS (1987) The hypothesis of antarctic larval starvation examined for the asteroid Odonaster validus. Limnol Oceanogr 32:686-690

Pauley G, Boring L, Strathmann RR (1985) Food limited growth and development of larvae: experiments with natural sea water. J Exp Mar Biol Ecol 93:1-10

Plate S, Husemann E (1994) Identification guide to the planktonic polychaete larvae around the island of Helgoland (German Bight). Helgoländer Meeresunters 48:1-58

Qian PY, Chia FS (1993) Larval development as influenced by food limitation in two polychaetes: Capitella sp. and Polydora Ligni Webster. J Exp Mar Biol Ecol 166:93-105

Rasmussen E (1956) Faunistic and biological notes on marine invertebrates III. The reproduction and larval development of some polychaetes from the Isefjord, with some faunistic notes. Biol Medd Dan Vid Selsk 23:1-84

Rasmussen E (1973) Systematics and ecology of the Isefjord fauna (Denmark). Ophelia 11:1-495

Rice SA (1975) The life history of Polydora ligni (Polychaeta: Spionidae) including a summary of reproduction in the family Spionidae. Master thesis, California State University, Long Beach

Rumrill SS (1990) Natural mortality of marine invertebrate larvae. Ophelia 32:163-198

Simon JL (1968) Occurrence of pelagic larvae in Spio setosa Verril, 1983 (Polychaeta: Spionida). Biol Bull 134:503-515

Stenalt E, Johansen B, von Lillienskjold S, Hansen BW (1998) A mesocosm study of Mytilus edulis larvae and postlarvae, including the settlement phase, exposed to a gradient of tributyltin (TBT). Ecotox Environ Safety 41:212-225

Tenore K, Chesney E (1985) The effects of interaction of rate of food supply and population density on the bioenergetics of the opportunistic polychaete, Capitella capitata (Type I). Limnol Oceanogr 30:1188-1195

Thorson G (1946) Reproduction and larval development of Danish marine bottom invertebrates, with special reference to the planktonic larvae in the sound (Øresund). Medd Kom Dan Fisk Hav 4:1-523

Wang WX. Widdows J (1991) Physiological responses of mussel larvae Mytilus edulis to environmental hypoxia and anoxia. Mar Ecol Prog Ser 70:223-236

Zarac RN (1991) Population ecology of Polydora ligni (Polychaeta: Spionidae). Seasonal variation in population characteristics and reproductive activity. Mar Ecol Prog Ser 77 : $197-206$

Submitted: July 27, 1998; Accepted: November 18, 1998 Proofs received from author(s): March 10, 1999 